\title{
Media Kamus Bahasa Indonesia Bergambar untuk Meningkatkan Pemahaman Kosakata Siswa Tunarungu
}

\author{
Putri Buchika Widamelia, M. Shodiq AM \\ Universitas Negeri Malang \\ Email:putribuchikawidamelia@gmail.com
}

\begin{abstract}
Abstrak: Pemahaman kosakata termasuk dalam hambatan komunikasi anak tunarungu. Hal tersebut mengakibatkan sedikitnya pemahaman kosakata anak tunarungu. Pada penelitian inimenggunakan penelitian kuantitatif dengan metode Pre-Experimental Designs (nondesigns) dan bertujuan untuk mendeskripsikan pengaruh media kamus Bahasa Indonesia bergambar terhadap pemahaman kosakata. Analisis data menggunakan dua jenis data yaitu Pre test yang nilai rata-ratanya 56,1 dan Post test dengan nilai rata-rata 91,6. Hasil perhitungan Uji Wilcoxon diperoleh nilai $=\mathbf{0}$. Nilai kritis untuk uji Wilcoxon $\alpha=0,05$ dan $\mathrm{n}=6$ (jumlah sampel) dari daftar uji Wilcoxon dan diperoleh $=\mathbf{2}$. Dari perhitungan tersebut dinyatakan bahwa diterima dan ditolak, sebab Thitung (0) $\leq$ Ttabel (2). Maka bisa dikatakan bahwa terdapat pengaruh yang signifikan menggunakan media Bahasa Indonesia bergambar terhadap pemahaman kosakata anak tunarungu.
\end{abstract}

Kata Kunci: Kamus Bahasa Indonesia bergambar, Pemahaman Kosakata, Tunarungu..

\begin{abstract}
Mastery of vocabulary are in the communication's obstacle hearing impairment children. That makes the the mastery of vocabulary by children with hearing impairment is lacking. This research use quantitative research with pre-experimental design (nondesign) method and the main objective of this reseach is describe the influence of illustrated dictionary media on vocabulary mastery, analyze the data and using two kind of data that is. Pre test the average score is 56,1 and post-test the average score is 91,6 the result of Wilcoxon test is Thitung $=0$, the critical score for Wilcoxon test is $a=0,05$ and $n=6$ (the amount of sample) from Wilcoxon table obtained Ttable $=2$. From the calculation above can be concluded that $\mathrm{Hi}$ accepted and Ho rejected, because Thitung $(0) \leq$ Ttabel (2). so can be concluded that there are a significant influence using illustrated indonesian dictionary media on vocabulary of children with hearing impairment in SDLB BC Kepanjen
\end{abstract}

Keywords: illustrated Indonesian dictionary media,vocabulary mastery, hearing impairment

Tunarungu ialah keadaan kehilangan fungsi indra pendengaran yang berakibat seseorang memiliki gangguan untuk menangkap rangsangan yang masuk kedalam indra pendengarnya. Dalam kata lain tunarungu memiliki gangguan dalam pendnegarannya sehingga berakibat terjadinya gangguan dalam komunikasinya. Rangkuman dari Lakshita (2012) bahwa perkembangan bahasa anak tunarungu berkaitan dengan indera pendengaran, hal ini mengakibatkan anak tunarungu memiliki keterbatasan pada perkembangan Bahasa dan bicara, dapat menirukan suara tetapi melalui peniruan visual dan anak tunarungu memerlukan pembinaan secara khusus danintensif sesuai kemampuan dan tingkat ketunarunguan yang dimiliki. Pada anak tunarungu terdapat hambatan terhadap pendengaran yang akan berpengaruh juga pada kemampuan berbicaranya. Dengan terganggunya kemampuan bicara dan pendengaran makan akan berpengaruh pula terhadap perkembangan dan pengembangan pendidikannya. Anak tunarungu bisa memanfaatkan indra pengelihatan untuk mengumpulkan informasi dari lingkungannya. Banyak hal yang dilakukan untuk pengembangan potensi diri anak tunarungu melalui modifikasi pembelajaran dan penggunaan media pembelajaran yang sesuai.

Menurut Efendi (2008) masalah-masalah yang sering dialami pada anak tunarungu akibat terhambatnya komunikasi dengan sekitarnya ialah miskin kosakata, susah memahami ungkapan berkiasan, sulit mengartikan kata-kata abstrak, sulit memahami irama dan makna bahasa. Dengan masalah tersebut terkadang tunarungu mengalami kesalahpahaman dalam menginterpretasikan sesuatu. Masalah yang terlihat pada tunarungu salah satunya adalah miskin kosakata dan sulit untuk memahami kata-kata. Padahal kedua hal tersebut berperan sangat penting dalam berkomunikasi. Menurut Bunawan dan Yuwati (2000:33) Bahasa ialah media yang memungkinkan seseorang menyampaikan pikirannya kepada orang lain, mengidentifikasikan perasaanya yang dalam, dan menjelajahi dunianya melampaui pandangan masa kini. 
Tabel 1. Hasil pre-test pemahaman kosakata kata benda

\begin{tabular}{llll}
\hline No & Nama & Nilai & Rata-rata \\
\hline 1 & AA & 57,8 & \\
2 & AC & 52,6 & \\
3 & EK & 60,5 & 56,1 \\
4 & FA & 52,6 & \\
5 & SM & 50 & \\
6 & SN & 63,1 & \\
\hline JUMLAH & & 336,6 & \\
\hline
\end{tabular}

Dengan demikan bahasa bagi seseorang selain sebagai media untuk dapat mengekpresikan keinginan hatinya, melalui bahasa pula orang dapat berimajinasi dan bercerita tentang masa yang akan datang. Intinya bahwa siswa tunarungu khususnya dalam penguasaan tata kalimat pada pembelajaran Bahasa Indonesia perlu mendapatkan pemecahan masalah (Pradipta, 2017). Hasil pengamatan yang telah diperoleh oleh peneliti pada siswa tunarungu kelas VI di SDLB BC Kepanjen adalah banyak siswa yang mengalami kesulitan mengartikan suatu kata yang ditunjukkan guru. Sehingga dalam menjawab pertanyaan, siswa masih kesulitan menjawabnya. Dari tujuh siswa hanya tiga siswa yang dapat menjawab benar. Guru masih menjelaskan dengan mengulang-ulang pemberian soal serupa hingga siswa tunarungu dapat memahami kata tersebut. Pada pengamatan yang peneliti lakukan, dari 16 kata benda yang diberikan rata-rata siswa dapan menjawab kurang dari 6 kata. Kata-kata yang diajarkan guru terbatas dalam benda yang ada didalam lingkup kelas. Cara yang guru gunakan sejauh ini dapat digunakan pada siswa untuk memperbanyak kata yang siswa miliki. Tetapi tidak semua kosakata sulit ada pada penjelasan yang diberikan guru. Sehingga dalam pembelajaran berlangsung siswa mendapatkan sedikit kata baru. Hal ini disebabkan karena kurangnya media yang digunakan guru dalam pembelajaran.

Hambatan pendengaran yang dialami tunarungu menyebabkan ia menggunakan indera lainnya sebagai pencari informasi yang maksimal. Indera yang dominan digunakan anak tunarungu yaitu indera pengelihatan. Karena tunarungu dominan menggunakan indera pengelihatan, maka pembelajaran yang dibutuhan anak tunarungu berupa pembelajaran visual. Penggunaan media yang berfokus kepada penglihatan juga bisa membantu dalam pembelajaran anak tunarungu. pendapat Rusman dkk (2013) media pembelajaran ialah alat pembawapesan yang diguankan untuk keperluan penbelajaran dan juga merupakan saran fisik dalam menyampaikan materi pelajaran.

Penelitianterdahuluyangrelevan dengan penelitain ini adalah Karimah (2014) yang berjudul “ Pengaruh Penggunaan Media Papan Flanel (Flankat) Terhadap Penguasaan Kosakata Siswa Kelas X SMALB-B YPTB
Kota Malang". Pemerolehan hasil dalam penelitian tersebut adalah hasil belajarmenggunakan media flankat berbasis kosakata menunjukkan ada kemajuan nilai rata-rata hasil belajar dibandngkan dengan secara konvensional. Dengan kata lain penguasaan kosakata dibutuhkan media dalam membantu pembelajarannya dan juga subjek dalam penelitian sebelumnya adalah siswa SMALB. Peneliti menyimpulkan bahwa hingga masa SMA, siswa tunarungu masih mengalami hambatan dalam penguasaan kosakata Bahasa Indonesia. Penelitian lainnya yang relevan dengan penelitian ini Lutfiyah (2008) yang berjudul "Peningkatan pembendaharaan kosa kata dasar pada anak tunagrahita sedang dengan media kartu kata". Dalam penelitian ini bermaksud memperoleh gambaran tentang ada tidaknya peningkatan kemampuan anak tunagrahita sedang dalam perbendaharaan kosa kata dasar. Dengan menggunakan media kartu gambar, kosa kata dapat tersampaikan melalui visual dan anak dapat menungkapkan secara verbal serta lebih mudah dipahami. Subjek dalam penelitian ini anak tunagrahita sedang, dan minimnya kosa kata yang dimiliki anak, sehingga anak hanya berkomunikasi secara non verbal. Dengan demikian yang menjadi target behavior adalah meningkatkan pembendaharaan kosa kata dasar pada anak tunagrahita sedang. Target behavior diukur secara kuantitatif. Metode penelitian menggunakan Single Subject Research (SSR).

\section{METODE}

Penelitian ini memiliki tujuan untuk mendeskripsikan pemahaman kosakata kata benda pada tema 1 "Tugasku" subtema 1 "tugasku dirumah" kelas VI murid tunarungu di SDLB BC Kepanjen sebelum diterapkan perlakuan dan sesudah diterapkan perlakuan. Perlakuan yang diberikan pada penelitian ini adalah media kamus Bahasa Indonesia bergambar. Alasan peneliti menggunakan metode ini karena peneliti ingin mengetahui pengaruh media kamus Bahasa Indonesia bergambar terhadap pemahaman kosakata anak tunarungu kelas VI di SDLB BC Kepanjen.

\section{HASIL DAN PEMBAHASAN}

\section{Hasil}

Pelaksanaan pre-test dilaksanakan pada hari rabu 10 mei 2017 pada siswa tunarungu kelas VI SDLB BC Kepanjen. Dalam pelaksanaan pre-test, siswa diberi penjelasan bagaimana cara mengerjakan soal yang telah diberikan dan materi apa saja yang tercantum pada soal pre-test. Namun siswa masih kesulitan mengerjakan soal yang diberikan. Siswa selalu mengeluh kepada peneliti untuk dibantu menjawab soal yang diberikan. Adapun data hasil pre-test yang dikerjakan sebelum mendapat intervensi dapat dilihat pada tabel 1 . 
Tabel 2 Hasil pos-test pemahaman kosakata kata benda

\begin{tabular}{llll}
\hline No & Nama & Nilai & Rata-rata \\
\hline 1 & AA & 89,4 & \\
2 & AC & 86,8 & \\
3 & EK & 94,7 & \\
4 & FA & 86,8 & 91,6 \\
5 & SM & 97,3 & \\
6 & SN & 94,7 & \\
\hline JUMLAH & & 549,7 & \\
\hline
\end{tabular}

Tabel 3 Hasil Perbandingan pre-test dan pos-test

\begin{tabular}{llll}
\hline No & Nama & Nilai Pre-test & Nilai Post-test \\
\hline 1 & AA & 57,8 & 89,4 \\
2 & AC & 52,6 & 86,8 \\
3 & EK & 60,5 & 94,7 \\
4 & FA & 52,6 & 86,8 \\
5 & SM & 50 & 97,3 \\
6 & SN & 63,1 & 94,7 \\
\hline JUMLAH & 336,6 & 549,7 \\
\hline \multicolumn{2}{l}{ Rata-rata } & 56,1 & 91,6 \\
\hline
\end{tabular}

Tabel 4 Analisi Data Uji Wilcoxon

\begin{tabular}{|c|c|c|c|c|c|c|}
\hline & \multicolumn{2}{|l|}{ Nilai } & \multirow[b]{2}{*}{$\begin{array}{l}(\mathbf{Y}- \\
\mathbf{X})\end{array}$} & \multirow[b]{2}{*}{ Rank } & \multicolumn{2}{|l|}{ Tanda } \\
\hline & $\begin{array}{l}\text { Pre- } \\
\text { test } \\
(X)\end{array}$ & $\begin{array}{l}\text { Post-test } \\
\text { (Y) }\end{array}$ & & & Positif & Negatif \\
\hline 1 & 57,8 & 89,4 & 31,5 & 1 & +1 & $\mathbf{0}$ \\
\hline 2 & 52,6 & 86,8 & 34.2 & 4 & +4 & $\mathbf{0}$ \\
\hline 3 & 60,5 & 94,7 & 34,2 & 4 & +4 & $\mathbf{0}$ \\
\hline 4 & 52,6 & 86,8 & 34,2 & 4 & +4 & $\mathbf{0}$ \\
\hline 5 & 50 & 97,3 & 47,3 & 6 & +6 & $\mathbf{0}$ \\
\hline 6 & 63,1 & 94,7 & 31,6 & 2 & +2 & $\mathbf{0}$ \\
\hline \multicolumn{3}{|c|}{ Jumlah } & & & $T=21$ & $=0$ \\
\hline
\end{tabular}

Berdasarkan tabel 1 dapat disimpulkan bahwa hasil pre-test pemahamana awal siswa dalam penguasaan kosakata sebelum diberikan intervensi dengan menggunakan media kamus Bahasa Indonesia bergambar memperoleh nilai tertinggi sebesar 63,1 dan nilai terendah adalah 50 .

Soal yang diberikan pada tahap post-test sama dengan soal yang diberikan pada saat tahap pre-test hal ini dikarenakan apabila soal yang diberikan berbeda maka nilai yang dihasilkan tidak dapat dijadikan pembamnding antara pre-test dan post-test, sebab memiliki bobot soal yang berbeda. Post-test diberikan setelah siswa mendapat perlakuan sebanyak tiga kali dalam pembelajaran dengan memanfaatkan media kamus Bahasa Indonesia bergambar untuk pemahaman kosakata. Pada saat mengerjakan post-test siswa terlihat serius mengerjakan soal dibandingkan saat mengerjakan soal pre-test. Tidak ada lagi siswa yang bertanya mengenai cara mnegrjakan soal pada saat post-test berlangsung. Mereka hanya mengandalkan ingatan mereka tentang gambar-gambar yang telah di hafalkan beberapa hari. Penggunaan media kamus Bahasa Indonesia bergambar memudahkan siswa dalam mengerjakan soal tanpa harus bertanya dan melihat bagaimana teman mereka dalam mengerjakan, hal tersebut menjadikan siswa mampu mengerjakan post-test sesuai dengan kemampuan mereka masing - masing. Adapun hasil post-test dapat dilihat pada tabel 2. Berdasarkan tabel 2 dapat disimpulkan hasil belajar post-test siswa tunarungu kelas VIdi SDLB BC Kepanjen dalam pemahaman kosakata memperoleh nilai 97,3 sebagai nilai tertinggi dan 86,8 sebagai nilai terendah. Dapat disimpulkan bahwa semua siswa mengalami peningkatan hasil belajar setelah diberikan tiga kali perlakuan. Dalam penelitian ini setelah mengetahui hasil dari nilai pre-test dan posttest maka dilakukan rekapitulasi data yang berguna untuk mengetahui ada atau tidaknya peningkatan hasil belajar setelah dilakukan perlakuan. Berdasarkan data dari tabel 3, Peningkatan hasil belajar ini dapat diketahui melalui hasil nilai yang diperoleh pada saat post-test yang ditandai dengan lebih tingginya nilai dibanding pada saat pre-test. Dari data yang disajikan diatas dapat disimpulkan bahwa nilai rata-rata pretest lebih rendah daripada nilai rata-rata post-test. Perbedaan nilai rata-rata tersebut menunjukkan adanya perbedaan pemahaman kosakata pada hasil pre-test yaitu sebelum diberi perlakuan dengan hasil post-test dengan menggunakan media kamus Bahasa Indonesia bergambar.

Berdasarkan perhitungan uji Wilcoxon, seperti pada tabel 4.4 di atas diperoleh nilai hasil belajar yang menunjukkan peningkatan yaitu dengan nilai tertinggi 94,7 dan nilai terendah 86,8 . Nilai pretest dan posttest semua anak tidak ada yang berselisih negatif (-), maka semua anak diberi tanda positif $(+)$. Selanjutny rangking bertanda positif dan negatif masing - masing dijumlahkan, kemudian hasil penjumlahan yang paling kecil dijadikan . Berdasarkan perhitungan diperoleh niali $=\mathbf{0}$, yaitu jumlah yang harga mutlaknya paling kecil. Nilai kritis untuk uji Wilcoxon $\alpha=0,05$ dan $n=6$ (jumlah sampel) dari daftar uji Wicoxon diperoleh $=\mathbf{2}$

Pengujian hipotesis dalam suatu penelitian merupakan hal yang paling penting karena diperlukan untuk menguji kebenaran suatu hipotesis yang diajukan dalam penelitian.Hipotesis yang diajukan dalam penelitian ini "Pengaruh kamus Bahasa Indonesian bergambar terhadap pemahaman kosakata siswa tunarungu di SDLB BC Kepanjen”.

Berdasarkan perhitungan melalui uji Wilcoxon dengan $\mathrm{n}=6$ pada taraf signifikan 0,05 diperoleh $=$ 2, maka diterima karena $(0) \leq(2)$ artinya hipotesis 
yang diajukan diterima. Hal ini menunjukkan bahwa penggunaan kamus Bahasa Indonesia bergambar mempunyai pengaruh terhadap pemahaman kosakata siswa tunarungu di SDLB BC Kepanjen.

\section{Pembahasan}

Berdasarkan rekapitulasi hasil pre-test sebelum diberikan treatment semua siswa mengalami kesulitan dalam menjawab soal mengenai kata benda. Sebagian besar siswa tidak mengetahui nama benda bila di pasangkan dengan kegunaan benda tersebut. Karena kesulitan untuk memahami kosakata tersebut siswa mendapatkan nilai pre-test yang kurang baik.

Dalam pembelajaran bahasa unit terkecil dan terpenting dalam pembelajarannya adalah kosakata. Menurut Tarigan (1989) Berdasarkan hasil analisis pretest diketahui pemahaman siswa sebelum diberikan perlakuan (treatment) masih cukup rendah. Hal ini terlihat dari rata-rata nilai pretest yakni 56,1. Dengan nilai rata-rata tersebut bisa dibilang pemahaman siswa terhadap penguasaan kosakata masih berada pada kategori kurang. Akibatnya adalah siswa tunarungu hanya memanfaatkan indra penglihatannya dalam menangkap informasi. Hal ini tentu berpengaruh akan perbendaharaan kosakata tunarungu tersebut.

Pada saat pemberian pretest terlihat banyak sekali jawaban siswa yang salah. Dalam menyebutkan nama-nama benda di dapur siswa masih belum tahu. Meskipun ada beberapa benda yang cukup familiar bagi siswa, namun secara keseluruhan pemahaman siswa terhadap benda-benda di lingkungannya masih rendah. Kemudian ketika siswa disuruh menunjuk objek berdasarkan namanya, seperti misalnya siswa disuruh mencari kemoceng terlihat beberapa siswa cukup bingung. Selain itu, siswa tunarungu juga mengalami masalah pada penggunaan benda dan fungsi benda. Siswa seringkali salah dalam membedakan kegunaan dandang dan wajan, ataupun perbedaan kegunaan antara gunting rumput dengan gunting biasa. Dengan ini tidak dapat dipungkiri bahwa anak tunarungu mengalami hambatan dalam mengenali benda disekitarnya.

Tes dalam penelitian ini terbagi menjadi 3 tipe soal yang terdiri dari 5 soal pilihan ganda, 5 soal mencocokkan, dan 5 soal menuliskan nama benda. Sehingga jumlah keseluruhan soal adalah 15 dengan skor maksimal adalah 100. Nilai tes sendiri diperoleh dari nilai pretest dan nilai posttest siswa. Dalam penelitian ini siswa mengerjakan soal pretest tanpa diberikan perlakuan (treatment) berupa pembelajaran menggunakan media kamus bergambar. Tahap pretest digunakan untuk mengukur kemampuan awal siswa, pada tahap ini siswa terlihat bingung dalamm mengerjakan soal. Selain itu, siswa juga sering bertanya tentang jawaban dari soal.

Pada penelitian ini pemberian intervensi dilakukan sebanyak tiga kali selama tiga hari berturutturut. Intervensi yang dilakukan. Pada pemberian intervensi pertama pada saat peneliti menanyakan tentang pelajaran yang diajarkan sebelumnya pada siswa, siswa kurang bisa mengingat materi dikarenakan sebelumnyatidak diberikan bantuan media kamus bahasa indonesia bergambar. Saat peneliti menjelaskan tentang gambar, nama benda anglo,baskom, blender, dandang, dispenser, garpu, gelas, gunting rumput, kemoceng dan kompor dengan menggunakan media kamus Bahasa Indonesia bergambar, pada tahap ini siswa sangat bersemangat melihat dan membaca serta mengerti dengan media yang diberikan peneliti. Setelah dibagi menjadi dua kelompok terlihat bahwa siswa sangat antusias dikarenakan siswa menggunakan media kamus Bahasa Indonesia bergambar sebagai permainan tebak-tebakan menebak nama benda tersebut pada teman satu kelompoknya secara bergantian. Pada pemberian intevensi pertama pemahaman siswa pada sepuluh kosakata pertama sudah baik dilihat dari diskusi yang dilakukan saat berkelompok, hampir semua bisa menebak sepuluh kosakata beserta fungsinya.

Pada pemberian intervensi kedua pada saat peneliti menanyakan tentang pelajaran yang diajarkan sebelumnya pada siswa, siswa sudah dapat menjelaskan satu hingga tiga kosakata dengan fungsinya. Antusiasa siswa dalam menerima sepuluh kosakata selanjutnya sangan terlihat pada saat peneliti memperlihatkan media kamus Bahasa Indonesia bergambar kepada para siswa dan meminta siswa maju secara bergantian untuk menjelaskan kosakata yang ada didalam media. Siswa saling berebutan untuk maju dan menggunakan media kamus Bahasa Indonesia bergambar dan menjelaskan kepada siswa lain tentang kosakata baru tersebut.

Pada pemberian intervensi ketiga pada saat peneliti menanyakan tentang pelajaran yang diajarkan sebelumnya pada siswa mampu menjawab lebih dari Sembilan kosakata beserta fungsinya. Saat peneliti menuliskan berbagai kata di papan tulis, antusias siswa terlihat saat guru memilih siswa untuk maju pertama, siswa saling berlomba mengangkat tangan. Saat peneliti melakukan tanya jawab secara keseluruhan kosakata, masing-masing siswa sudah dapat menyebutkan lebih dari lima belas kosakata beserta fungsinya. Pemberian intervensi ini sangatlah penting bagi anak tunarungu. Dengan menggunakan intervensi ini anak tunarungu dapat mengetahui kosakata kata benda dan kata kebersihan serta mengetahui fungsi dan gambar dari kosakata yang ada di kamus Bahasa Indonesia bergambar. Pemberian treatment ini sangatlah penting bagi anak tunarungu. Dengan menggunakan treatment ini anak tunarungu dapat mengetahui kosakata kata benda dan kata kebersihan serta mengetahui fungsi dan gambar dari kosakata yang ada di kamus Bahasa Indonesia bergambar.

Setelah pemberian treatment sebanyak tiga kali, kemampuan siswa tunarungu kelas VI di SDLB BC Kepanjen mendapatkan peningkatan . hal ini 
ditunjukan dengan meningkatnya nilai post test yang dilakukan. Pelaksanaan penelitian dilakukan pada siswa tunarungu kelas VI SDLB Kepanjen malang yang berjumlah 6 siswa. Pada kegiatan ini siswa sudah diberikan perlakuan (treatment) dengan menggunakan kamus bahasa Indonesia bergambar. Siswa menjawab posttest yang terdiri dari 15 butir soal. Pada tahap posttest ini bertujuan untuk mengetahui pengaruh keefektifan media kamus bahasa Indonesia bergambar.

Amy, dkk. (2011) beropini bahwa memori adalah suatu proses penyimpanan dan mengeluarkan kembali informasi yang didapat dari proses belajar. Jadi, memori adalah keakuratan otak peserta didik dalam mengingat, baik mengingat kosa kata, mengingat gambar pada media, maupun menegerjakan soal tes tulis. Berdasarka pernyataan diatas peneliti menyimpulkan bahwa pemberian treatment selama tiga hati berturut-turut dapat mempengaruhi memori peserta didik. Pada saat pemberian posttest terlihat jawaban siswa banyak yang benar. Dalam menyebutkan nama-nama benda dalam kamus bahasa Indonesia tersebut terlihat siswa mampu menjawabnya dengan benar. Lebih lanjut lagi siswa juga mampu dalam menjelaskan fungsi-fungsi benda dalam kamus bahasa Indonesia bergambar tersebut.

Pengaruh atau tidaknya media tersebut dapat terlihat dari nilai yang diperoleh selama posttest dengan menggunakan bobot soal yang sama pada saat pelaksanaan pretest. Pemahaman siswa terhadap benda-benda dalam kehidupan sehari-harinya terdapat peningkatan. Setelah diberikan perlakuan (treatment), dalam mengerjakan soal yang diberikan siswa terlihat lebih teliti dan terlihat lebih tenang saat mengerjakan. Hal ini terlihat dari jumlah jawaban benar yang didapat siswa cukup banyak, meskipun dalam penulisan terkadang terdapat typo yang dialami siswa.

Berdasarkan uraian diatas, dapat disimpulkan bahwa terdapat perbedaan nilai sebelum dan sesudah penggunaan media kamus bahasa Indonesia bergambar. Maka dapat ditarik kesimpulan bahwa penggunaan media kamus bahasa Indonesia bergambar berpengaruh signifikan terhadap pemahaman siswa pada kosakata kata benda. Media Pembelajaran sangat penting dalam menunjang kegiatan belajar dan pembelajaran di sekolah. media pembelajaran yang baik dapat dilihat dari keaktifan siswa dikelas, memberikan pengalaman yang menyenangkan bagi siswa, dan memenuhi kebutuhan belajar siswa. Penggunaan media pembelajaran sangat mendukung proses pembelajaran, sehingga penyampaian pesan dan isi pembelajaran dapat tercapai secara maksimal.

Dari segi fisik, tidak ada perbedaan yang signifikan antara anak-anak yang memiliki masalah pendengaran dan anak-anak normal. Hal yang membedakan adalah komunikasi. Anak-anak yang mengalami kehilangan pendengaran biasanya mengalami masalah dalam pembelajaran disekolah (Jamila, 2008). Penggunaan media dalam proses pembelajaran di sekolah sangat membantu siswa dan guru dalam menyampaikan pesan dan materi pembelajaran. Selain itu media juga berfungsi untuk membangkitkan motivasi dan minat belajar siswa, memudahkan siswa dalam memahami materi pembelajaran, dan membuat materi pembelajaran terlihat lebih menarik.

Penggunaan media kamus bergambar bahasa indonesia berpengaruh terhadap pemahaman kosakata siswa tunarungu SDLB Kepanjen. Hal ini dapat dibuktikan dengan perbedaan rata-rata pretest yang berjumlah 56,1 dan rata-rata posttest berjumlah ratarata 91,6. Pembelajaran bahasa khususnya pada materi mengenal benda-benda sekitar kita dengan menggunakan media Kamus bahasa indonesia bergambar dapat meningkatkan kualitas belajar karena proses pembelajaran jadi terasa aktif dan menyenangkan. Siswa jadi sering berebut menjawab pertanyaan, dan tidak ragu-ragu dalam bertanya. Karena hal ini tentunya materi dapat tersampaikan dengan baik.

\section{KESIMPULAN DAN SARAN}

\section{Kesimpulan}

Proses pembelajaran dikatakan berhasil dikarenakan cara pengaplikasian media yang sesuai dengan kebutuhan. Dalam pembelajaran, memilih media pembelajaran yang tepat dapat membantu siswa untuk mudah memahami materi yang disampaikan. Pada tahap pre-test, kemampuan pemahaman kosakata pada siswa tunarungu sebelum diberikan perlakuan berupa interfensi mendapatkan rata-rata nilai 56,1 dihitung dari 6 orang subjek. Pada tahap posttest, kemampuan pemahaman kosakata pada siswa tunarungu sesudah diberi perlakuan berupa interfensi sebanyak 3 kali menggunakan media kamus Bahasa Indonesia bergambar mendapatkan rata-rata nilai 91,6, dapat diartikan bahwa setelah diberikan perlakuan dengan menggunakan media kamus Bahasa Indonesia bergambar terjadi peningkatan nilai.

Terdapat pengaruh kamus Bahasa Indonesia bergambar terhadap pemahaman kosakata siswa tunarungu di SDLB BC Kepanjen. Berdasarkan hasil pengujian hipotesis menunjukka adanya perbedaan yang signifikan antaar pemahaman kosakata sebelum dan sesudah diberikan interfensi dengan menggunakan kamus Bahasa Indonesia bergambar yaitu nilai T hitung $<\mathrm{T}$ tabel maka Hi diterima dan Ho ditolak.

\section{Saran}

Berdasarkan pada kegitan penelitian yang dilakukan, maka peneliti mengajukan saran untuk guru agar dapat melanjutkan penelitian dengan menggunakan media kamus Bahasa Indonesia bergambar namun tidak hanya terbatas pada kosakata kata benda alat dapur dan alat kebersihan saja, kamus 
Bahasa Indonesia bergambar ini juga dapat digunakan untuk melatih siswa dalam mengenalkan warna, bentuk angka, dan kosakata lainnya.

Selain itu guru diharapkan menerapkan pembelajaran dengan menggunakan kamus Bahasa Indonesia bergambar dalam menambah pemahaman kosakata anak berpengaruh dalam pemahaman kosakatanya. sehingga guru dapat menggunakan kamus Bahasa Indonesia bergambar sebagai salah satu media pembelajaran. Diharapkan guru dapat memanfaatkan kamus Bahasa Indonesia bergambar dalam pembelajaran lainnya di dalam kelas.

\section{DAFTAR RUJUKAN}

Amy dkk. (2011). Media Pendidikan (penelitian, pengembangan, dan pemanfaatannya). Jakarta. Rajawali

Bunawan, L. dkk. (2000). Penguasaan Bahasa Anak Tunarungu. Jakarta: Yayasan Santri Rama
Effendi, M (2008). Pengantar Psikopedagogik Anak Berkelainan. Jakarta: Bumi Aksara.

Lakshita. N. (2012). Bahasa Isyarat Untuk Anak Tunarungu Dasar. Jogjakarta: javalitera

Pradipta, R. F., Ummah, U. S., \& Susilawati, S. Y. PENGARUH PENGGUNAAN MEDIA GAMBAR BERSERI TERHADAP PENINGKATAN PENGUASAAN TATA KALIMAT PADA SISWA TUNARUNGU.

Rusman, dkk. (2013). Pembelajaran Berbasis Teknologi Informasi dan Komunikasi. Depok: PT. RajaGrafindo Persada.

Sugiyono. (2011). Metode Penelitian Pendidikan. Bandung: Alfabeta.

Tarigan, Henry Guntur. (1989). Membaca sebagai Suatu Keterampilan Berbahasa. Bandung: Angkasa 